\title{
Functional and compositional responses in soil microbial communities along two metal pollution gradients: does the level of historical pollution affect resistance against secondary stress?
}

\author{
Hamed Azarbad $^{1,2} \cdot$ Maria Niklińska $^{1} \cdot$ Karolina Nikiel $^{1}$ • \\ Nico M. van Straalen ${ }^{2}$ - Wilfred F. M. Röling ${ }^{3}$
}

Received: 7 April 2015 / Revised: 5 June 2015 / Accepted: 12 June 2015 / Published online: 28 June 2015

(C) The Author(s) 2015. This article is published with open access at Springerlink.com

\begin{abstract}
We examined how the exposure to secondary stressors affected the functional and compositional responses of microbial communities along two metal pollution gradients in Polish forests and whether responses were influenced by the level of metal pollution. Basal respiration rate and community composition, as determined by $16 \mathrm{~S}$ rRNA gene-based denaturing gradient analysis, were studied in laboratory-incubated microcosms, containing soil samples taken from different locations in the field gradients, and subjected to secondary stress factors (arsenic, salt, benzo[a]pyrene or flooding). Soils adapted to higher metal contamination levels were more resistant to arsenic and salt stress compared to less polluted soils, indicating that functional and compositional responses to these stresses were related to the level of historical pollution in the long-term contaminated forest soils. However, community composition and functioning in soils along the two gradients were resistant to benzo[a]pyrene and flooding stress. Changes in respiration were significantly related to changes in community composition. Knowledge on the functional gene capabilities prior to adding the secondary stressor benefitted
\end{abstract}

Electronic supplementary material The online version of this article (doi:10.1007/s00374-015-1033-0) contains supplementary material, which is available to authorized users.

Hamed Azarbad

azarbad.hamed@gmail.com; hamed.azarbad@uj.edu.pl

1 Institute of Environmental Sciences, Jagiellonian University, Gronostajowa 7, 30-387 Krakow, Poland

2 Department of Ecological Science, Faculty of Earth and Life Sciences, VU University Amsterdam, De Boelelaan 1085, 1081 HV Amsterdam, The Netherlands

3 Department of Molecular Cell Physiology, Faculty of Earth and Life Sciences, VU University Amsterdam, De Boelelaan 1085, 1081 HV Amsterdam, The Netherlands understanding the functional responses toward additional stressors. Our study highlights that microbial communities selected for metal resistance in the field might also become more resistant against some secondary stress factors; however, the type of stress and the level of historical pollution play a decisive role in community-level responses toward secondary stressors.

Keywords Secondary stressors $\cdot$ Metal pollution . Forest soil $\cdot$ Microbial communities $\cdot$ Respiration rate

\section{Introduction}

Microbial communities can adapt to metal contamination by overexpressing genes conferring metal tolerance, by acquiring tolerance through horizontal gene transfer or via selective growth of metal-tolerant microorganisms (Turpeinen et al. 2004). Adaptation usually results in changes of community composition and the maintenance of soil functionality up to high concentrations of metals in soil (Frostegård et al. 1996; Bååth et al. 1998; Witter et al. 2000). Microbial processes differ in their susceptibility to stresses, with for instance nitrification being more sensitive than soil respiration (Domsch 1984). Because of its crucial importance for nutrient turnover and global carbon cycling, microbe-mediated decomposition of organic matter has been studied as the main functional variable in numerous studies on pollution effects in forest ecosystems (e.g., Grodziński et al. 1990; Laskowski et al. 1994; Pennanen et al. 1996).

Dealing with potentially toxic stress is energy-demanding for microorganisms due to the maintenance of metal resistance mechanisms. Therefore, it has been hypothesized that adapted communities will be increasingly susceptible to additional stressors (Degens et al. 2001). This has been shown for soils 
contaminated with copper, mercury, and zinc (Müller et al. 2001; Tobor-Kapłon et al. 2005, 2006a; Kools et al. 2008). For example, Tobor-Kapłon et al. (2005) observed lower respiration rates in $\mathrm{Cu}$-contaminated soil microbial community upon an additional lead stress ( $1 \mathrm{~g} \mathrm{~kg}^{-1}$ dry weight). Others have argued that ecosystems pre-exposed to stressors harbor microorganisms selected for their general resistance and so might be able to better withstand additional stressors. This will be the case if genetic or physiological changes provide resistance against more than one stress factor (Mertens et al. 2010). Experimental support for this idea has also been presented (Mertens et al. 2007; Tobor-Kapłon et al. 2006b; Philippot et al. 2008). Philippot et al. (2008), for example, showed a higher resilience of nitrate reduction activity to mercury stress (100 $\mathrm{mg} \mathrm{g}^{-1}$ dry weight) in microcosms pre-exposed to copper (50 $\mathrm{g} \mathrm{g}^{-1}$ dry weight). In the view of these contradictory results, it is difficult to generalize the influence of additional stressors on the functional and compositional stability of soil microbial communities in long-term metal-polluted soils.

The question of increased tolerance to secondary stress in stress-adapted communities is of great relevance to risk assessment. If adaptation to one stress factor leads to the loss of resistance against other stress factors, adaptation should not be considered a positive phenomenon and cannot, for instance, be taken as an argument to raise maximum acceptable concentrations of toxicants. If, however, adaptation provides a general improvement of vigor and resistance to many different stress factors, concerns about chronic pollution in the field might be moderated.

There are many factors that make it difficult to compare results of stress-on-stress studies. Firstly, investigated soils differed in (concentrations of) their initial stressors as well as various types of additional stressors; also, different microbial parameters were measured in the various studies. Secondly, soil properties may influence soil functioning (Kuan et al. 2007) and microbial diversity may increase in response to stressors by enhancing the spatial and temporal heterogeneity of the soil environment, promoting species coexistence (Degens et al. 2001; Fierer et al. 2003). Thirdly, soils from different ecosystems and geographical settings may contain very different soil microbial communities, which are adapted to the local environment and may differ in their response to additional stressors (Fierer et al. 2003).

Here, the effects of additional stressors on the functional and compositional response of soil microbial communities in two long-term metal-polluted areas, Olkusz and MiasteczkoŚląskie, in Southern Poland, were investigated. Both areas are highly contaminated since the 1970s by two zinc-and-lead smelters. The upper soil layers contain high levels of copper, lead, zinc, and other metals (e.g., up to $4300 \mathrm{mg} \mathrm{kg}^{-1}$ total $\mathrm{Zn}$ and $2900 \mathrm{mg} \mathrm{kg}^{-1}$ total $\mathrm{Pb}$ in Olkusz forest) placing them among the most polluted soils in Europe (Nowicki 1993; Azarbad et al. 2013). The long-term exposure to metal contamination has negatively influenced microbial biomass and basal respiration rates in these two gradients (Azarbad et al. 2013). However, this has not resulted in large shifts in microbial community composition, diversity, and functional capabilities, as revealed by high-resolution molecular approaches such as Illumina sequencing and GeoChip hybridization (Azarbad et al. 2015). Microarray analysis targeting functional genes revealed that metal pollution significantly affected abundances of metal resistance genes; however, no major change was observed in gene families relating to stress responses (e.g., oxidative stress, osmotic stress) nor in gene families related to pollutant metabolism (the capacity to degrade organic compounds such as polycyclic aromatic hydrocarbons).

We hypothesize that the degree to which microbial communities respond to secondary stress will depend on the nature of the secondary stressor, and the historical level of pollution, that is, the metal concentrations along the gradients. We previously observed significant changes in the abundance of metal resistance genes along the pollution gradients (Azarbad et al. 2015); therefore, we predict that communities exposed to the highest levels of metals would change relatively little in response to arsenic, a novel but metabolically related stress factor for these communities. However, with regard to osmotic stress (salt) and organic pollutant stress (benzo[a]pyrene), we predict that the communities will be equally susceptible, since diversity and abundances of functional genes important in responses to these stresses were not significantly affected by the level of historical pollution (Azarbad et al. 2015). We also expect limited changes upon flooding stress (inundation), since this stress frequently occurred in the past, as the result of prolonged rain events.

\section{Material and methods}

\section{Site description and soil sampling}

The Olkusz area is a major zinc and lead industry region in Southern Poland. Mining in the area goes back to medieval times, and intensive modern industry started in 1967 when the "Bolesław" zinc-and-lead smelter was established. Many years of mining and smelting have caused high metal concentrations in soils over a large area around the emission sources (Roberts et al. 2002). Miasteczko Ślaskie is a small town located ca. $48 \mathrm{~km}$ NE from the "Bolesław" smelter and home to another large zinc-and-lead smelter, constructed also in 1967. The intensive industry, especially in the 1970s when oldfashioned technological processes were used, resulted in heavy contamination of the environment with metals. The dominating tree species in the forests sampled in both areas is Scots pine (Pinus sylvestris) followed by common beech (Fagus sylvatica) (Niklińska et al. 2005). 
In the Olkusz area $(\mathrm{O})$, a transect was established extending from 1.9 to $31.8 \mathrm{~km}$ away from the smelter, and in the Miasteczko Śląskie area (M) from 2.1 to $52.6 \mathrm{~km}$ away from the source of pollution. Along each transect, six sampling locations were chosen, all in P. sylvestris forest stands, and at each location, a plot was laid out of approximately $100 \mathrm{~m}^{2}$. During three sampling times (May, June, and August 2013), ten samples (approximately 400-500 g wet mass per sample) of the organic topsoil $\mathrm{O}$ layer (about $10 \mathrm{~cm}$ thick) were randomly taken with a 5-cm-diameter soil auger, and the top $10 \mathrm{~cm}$ of each sample was used for analysis, sieved (mesh size $2 \mathrm{~mm}$ ), and mixed to obtain one representative sample per location and per month. Soil samples were stored at $4{ }^{\circ} \mathrm{C}$ for 10 days before all chemical and microbiological analyses were performed. Characteristics of the sampling locations, including total and soluble metal levels, have been previously reported (Azarbad et al. 2013, 2015). For the purpose of discussion, basic properties of the soil samples (e.g., pH, organic matter content, and water holding capacity) and levels of heavy metals used to calculate the toxicity indices (TI) have been included in Supplementary Table S1. TI is a combined measure of $\mathrm{Zn}, \mathrm{Pb}, \mathrm{Cu}$, and $\mathrm{Cd}$ concentrations, weighted against their toxicity. TI data were taken from Azarbad et al. (2013), in which we also presented concentrations of heavy metals and other soil parameters at the same locations investigated here. We used two different measures of metal pollution: $\mathrm{TI}_{\text {tot }}$ is based on total metal concentrations, and $\mathrm{TI}_{\mathrm{we}}$ is based on water-extractable concentrations (see Supplementary Table S1).

\section{Soil microcosm experiments for evaluating effect of different stressors}

Soil samples were incubated in microcosms corresponding to the $2 \times 6$ sampling locations along the gradients, which were all subjected to six treatments, and investigated at four time intervals (1, 20, 40, and 60 days). Each combination of sampling point, treatment, and time interval was run in triplicate. A total of 864 microcosms were thus installed. In addition, empty jars were placed among the microcosms to serve as controls for the respiration measurements (see below).

Before incubation, the microcosms were subjected to one of six treatments:

1. Untreated soil (soil without second stressor, as control): received only deionized water.

2. Arsenic: $\mathrm{As}_{2} \mathrm{O}_{5}$ was dissolved in deionized water and added to the soils to a final concentration of $2 \mathrm{~g} \mathrm{~kg}^{-1}$ dry weight. Due to the release of arsenic from industrial sources and in mining areas, its concentration in soils can reach $20 \mathrm{~g} \mathrm{~kg}^{-1}$ dry weight; therefore, we choose to use this concentration $\left(2 \mathrm{~g} \mathrm{~kg}^{-1}\right.$ dry weight $)$ to be close to the normal range of arsenic in polluted soils which induces a stress effect (Smith et al. 1998).

3. Benzo[a]pyrene: the soils were spiked with a solution of benzo[a]pyrene in dichloromethane $(500 \mathrm{ml})$ to obtain a final concentration of $0.5 \mathrm{~g} \mathrm{~kg}^{-1}$ dry weight, following the recommendations of Brinch et al. (2002). Briefly, $20 \%$ of the sample was spiked with the benzo[a]pyrene solution and mixed. After evaporation of the dichloromethane (overnight at $22^{\circ} \mathrm{C}$ ), the spiked subsample was mixed in with the rest $(80 \%)$ of the soil and shaken thoroughly. The benzo[a]pyrene concentration $\left(0.5 \mathrm{~g} \mathrm{~kg}^{-1}\right.$ dry weight $)$ corresponds to the PAHs "action level" in UK regulations (Jones et al. 1996).

4. Dichloromethane: as a control for benzo[a]pyrene.

5. Salt: a $\mathrm{NaCl}$ solution was added to the soil to obtain a final concentration of $6.5 \mathrm{~g} \mathrm{~kg}^{-1}$ dry weight. The salt concentration was corresponding to a concentration inducing stress in previous research (Tobor-Kapłon et al. 2005).

6. Flooding: the microcosms were inundated to cause a moisture level of $100 \%$ of WHC. Flooding is a common stressor for all communities, since prolonged periods of rain in autumn are common in the area.

Microcosms consisted of soil samples (20 g dry weight equivalent) placed in sterile $150-\mathrm{ml}$ plastic jars. Soil samples were adjusted to $50 \%$ of their water holding capacity (except for flooding stress) to obtain maximum respiration responses (Niklińska et al. 2005). After thorough mixing, all jars were partly closed to maintain stable humidity conditions but at the same time permitting aeration and then were subsequently incubated in constant conditions at $22{ }^{\circ} \mathrm{C}$ for 60 days in climate chambers. The water contents were kept at $50 \% \mathrm{WHC}$ (except for flooding stress), by monitoring weight and adding deionized water regularly to compensate for evaporative water loss, which was minimal throughout the experiment.

The measurements done at different times during the experiment were destructive (microcosms were sacrificed) resulting in complete independence of the temporal data. At $1,20,40$, and 60 days of incubation, soil basal respiration rate was determined as measure of the functional response. At days 1 and 60, subsamples were taken for denaturing gradient gel electrophoresis (DGGE) analysis. All microbial analyses described below were performed in triplicate (three independent microcosms).

\section{Soil BR}

Basal respiration (BR) was measured as described by Niklińska et al. (2005). Microcosms were placed into airtight jars. A small tube with $5 \mathrm{ml} 0.2 \mathrm{M} \mathrm{NaOH}$ was added to the air-tight jars to trap the evolved $\mathrm{CO}_{2}$. After $16 \mathrm{~h}, 2 \mathrm{ml}$ $0.5 \mathrm{M} \mathrm{BaCl}_{2}$ was added to the $\mathrm{NaOH}$ solution and the excess of sodium hydroxide was titrated with $0.1 \mathrm{M} \mathrm{HCl}$ in the 
presence of phenolphthalein as an indicator. The blanks were randomly selected empty jars (soil microcosms that did not receive soil).

\section{PCR-DGGE profiling}

DNA was extracted from $0.25 \mathrm{~g}$ soil using the PowerSoil DNA kit (MoBio Laboratories, Solana Beach, CA) following instructions of the manufacturer. To investigate general bacterial community, 16S ribosomal RNA (rRNA) gene sequences were amplified directly using the bacterial universal primer sets F357GC (CGC CCG CCG CGC GGC GGG CGG GGC GGG GGC ACG GGG CCT ACG GGA GGC AGC AG) and R518 (ATT ACC GCG GCT GCT GG) (Muyzer et al. 1995). One PCR reaction contained $12.5 \mu \mathrm{l}$ of GoTaq (Promega) ready mastermix, $1 \mu \mathrm{l}$ of $(0.01 \mathrm{mM})$ each primer, $9.5 \mu \mathrm{l}$ of DNA-free water (Promega; USA), and $1 \mu \mathrm{l}$ of undiluted DNA as template. Briefly, the reaction was carried out with a PCR activation step at $94{ }^{\circ} \mathrm{C}$ for $5 \mathrm{~min}$, followed by 35 cycles of amplification $\left(30 \mathrm{~s}\right.$ at $94^{\circ} \mathrm{C}, 30 \mathrm{~s}$ at $55^{\circ} \mathrm{C}$, and $1 \mathrm{~min}$ at $72{ }^{\circ} \mathrm{C}$ ) and a final extension at $72^{\circ} \mathrm{C}$ for $8 \mathrm{~min}$ in a T1 thermo-cycler (Biometra, Goettingen, Germany). PCR products were checked on $1.5 \%$ agarose gels, stained with ethidium bromide, and visualized under UV light.

DGGE was carried out as previously described (Röling et al. 2001) using a Dcode ${ }^{\mathrm{TM}}$ Universal Mutation Detection System (BIO RAD Laboratories). Amplified DNA fragments were loaded using a 1 -mm-thick $8 \%(w / v)$ polyacrylamide (ratio of acrylamide to bisacrylamide, 37.5:1) gel containing a linear/vertical gradient of $30-55 \%$ of urea-formamide. A customized DGGE marker (M12) with 12 bands at different positions was used as a reference to normalize band positions for comparisons between gels. The running conditions were $200 \mathrm{~V}$ at a constant temperature of $60^{\circ} \mathrm{C}$ in 7.51 of $1 \times \mathrm{TAE}$ buffer (40 mM Tris, $20 \mathrm{mM}$ acetic acid, $1 \mathrm{mM}$ Na-EDTA, $\mathrm{pH}$ 8.0) for $4 \mathrm{~h}$. The gels were stained in $1 \times$ TAE buffer containing $1 \mu \mathrm{g} / \mathrm{ml}(1 \mu \mathrm{l} / 100 \mathrm{ml}$ buffer $)$ of ethidium bromide on a horizontal shaker for $1 \mathrm{~h}$, and DNA was visualized using a UV transilluminator.

\section{Soil physicochemical analyses}

Water holding capacity (WHC) was measured as described by Boivin et al. (2006). Dry weight of the soils was measured after drying the samples for $12 \mathrm{~h}$ at $105^{\circ} \mathrm{C}$, and organic matter content was determined as loss on ignition at $550{ }^{\circ} \mathrm{C}(12 \mathrm{~h})$.

\section{Statistical analyses}

The percentage change in BR caused by each treatment (stressor), relative to the corresponding untreated soil (control sample) on day 1 and days 20,40, and 60, was taken as a measure of functional response. These percentages were arcsine-transformed to obtain normal distribution of the data and used in a univariate general linear model (GLM) with locations in the gradient as fixed factor for each time interval, to test for main effects of origin (location) of the soil. GLM analysis was performed for each field gradient separately. Tukey's HSD was applied as post hoc test.

DGGE profiles were analyzed to determine the similarity of community fingerprints of stressed samples to those of the controls, for a particular time point of sampling (day 1 or day 60 ) and sampling location, using a band assignmentindependent method employing the Pearson product-moment correlation coefficient (GelCompar II, Applied Maths, Kortrijk, Belgium). For example, for the May 2013 samples from location M1 in the Miasteczko Ślaskie transect, the stressed sample "arsenic-day 1" was compared to "control-day 1." These steps were also applied to samples from the two other months (June and August 2013) separately and then the average of these three similarity values, for each location and stressor, was taken as index of stress impact on community composition. Similarity values were arcsine-transformed to obtain a normal distribution of the data (Fry 1996) and used in a univariate GLM with location (origin) as fixed factor for each time interval, to test for main effects of origin (location) of the soil.

In order to determine whether the microbial communities at a certain location responded similarly to the four stresses, the similarities in communities exposed to different stressors ("between-stress") were compared to similarities in communities exposed to the same stressor ("within-stress"). For within-stress, DGGE profiles of the three microcosms exposed for 60 days to a particular stressor were compared to each other and the average similarity calculated. This was done for all four stressors separately and then the overall average withinstress similarity was calculated. The between-stress similarity was derived from comparing community profiles of two microcosms corresponding to the same location and sampling month but receiving different stressors, resulting in 18 similarity values (six comparisons between different stressors, performed for each of the three replicates) from which the average was taken.

Simple regression analysis was performed to verify the effect of metal pollution on relative changes (compared to the control) in respiration rates (BR days 1, 20, 40, and 60) and community similarity (days 1 and 60 ) across all locations in each transect. As a measure of metal pollution at each location, we used the combined concentrations of four metals (lead, zinc, cadmium, and copper), taken together in the toxicity index as defined in Azarbad et al. (2013). We used the total metal concentrations as a basis for the toxicity index $\left(\mathrm{TI}_{\text {tot }}\right)$. We refer the reader to Azarbad et al. (2013) for the original concentrations of heavy metals as well as other soil parameters in the field gradient. 
A Mantel test was used to test the relationship between relative changes in BR and similarity values of DGGE profiles, for each stressor and transect. Statistical analyses were performed using SPSS 21 and Statgraphics Centurion XV software (StatPoint, Herndon, VA, USA).

\section{Results}

\section{Responses to arsenic}

Arsenic treatment caused reductions in BR, compared to the corresponding control (the soil from the same location in the gradient, but not receiving a secondary stressor), in almost all soils after already 1 day of exposure (on average by $17 \%$ for Miasteczko Śląskie and 7 \% for Olkusz; Fig. 1a). Regression analysis revealed that the arsenic-induced decrease of BR on day 1 along the Miasteczko Ślaskie gradient was negatively affected by $\mathrm{TI}_{\text {tot }}(\beta=2.7, p=0.014)$; in other words, the largest effects of arsenic were observed in the lesser polluted soils. However, no significant relation was observed for Olkusz.

The reduction in BR in arsenic-stressed soils persisted throughout the 60-day incubation period (on the average $33 \%$ for Miasteczko Śląskie and $22 \%$ for Olkusz on day 60; Fig. 1a), and generally, the negative impact of arsenic became stronger over time for the lesser polluted soils in the Miasteczko Śląskie transect (Fig. 1a; M4-M6). Linear regression analysis underlines these observations, indicating that the decrease of BR on day $20(\beta=7.5, p<0.0001)$, day $40(\beta=4.9$, $p<0.0001)$, and day $60(\beta=4.4, p<0.0001)$ was greater with decreasing $\mathrm{TI}_{\text {tot }}$. In the Olkusz transect, the changes in BR tended to be higher in less polluted soils 60 days after applying arsenic stress (Fig. 1a), but no significant relationship ( $p=$ $0.06, \beta=2$ ) between TI and change in BR was evident.

One day of arsenic stress did not induce significant changes in soil bacterial community composition, as indicated by the similarity of DGGE profiles of these samples to those of corresponding control samples (at day 1 on average $51 \%$ for Miasteczko Śląskie and $61 \%$ for Olkusz, while the similarity among the controls was $70 \%$; Fig. 1b). However, 60 days after applying arsenic stress, microbial communities in the lesser polluted soils (M4 to M6) had considerably changed (on average $11 \%$ similar to the corresponding controls for M4-M6 and $16 \%$ for O6; Fig. 1b). Community profiles of the more polluted soils were more similar to those of the corresponding controls (on average $51 \%$ for M1-M3 and $81 \%$ for O1-O3; Fig. 1b). Regression analysis underlined these observations, revealing that similarity of the arsenic stress communities to the bacterial community composition in the corresponding control was positively related to $\mathrm{TI}_{\mathrm{tot}}$ in both transects (Miasteczko Ślaskie: $\beta=$ $3, p=0.006$; Olkusz: $\beta=3.1, p=0.006$ ).

Changes in bacterial community composition were positively correlated with changes in basal respiration in the
Miasteczko Śląskie (Mantel test; $R=0.80, p<0.001$ ) and Olkusz transects (Mantel test; $R=0.74, p<0.001$ ) at day 60 .

\section{Responses to benzo[a]pyrene}

One day after applying benzo[a]pyrene stress, BR had increased significantly $(p<0.05)$ in all soils along the transects, relative to the corresponding controls (on average Miasteczko Ślaskie, $26 \%$, and Olkusz, $17 \%$; Fig. 2a). These relative increases in BR were not significantly different between locations along each of the transects. BR had declined after 20 days in almost all locations and then remained stable over time. No significant association between $\mathrm{TI}_{\text {tot }}$ and $\mathrm{BR}$ was observed in both transects. Also, community composition had not changed significantly 1 day (on average $70 \%$ similar to control for Miasteczko Ślaskie and 64 \% for Olkusz; Fig. 2b) and 60 days (54 \% for Miasteczko Śląskie and 79 \% for Olkusz; Fig. 2b) after applying benzo[a]pyrene stress.

Since benzo[a]pyrene was spiked in with dichloromethane (DCM), we also investigated the potential impact of this solvent. Changes in BR due to DCM did not differ between locations at days 1,20 , and 40 in both transects (at day 1 on average $5 \%$ for Miasteczko Ślaskie and $2 \%$ for Olkusz; Fig. S1). Regression analysis revealed that the DCMinduced reduction in BR on day $40(\beta=4.7, p=0.044)$ and day $60(\beta=5.02, p<0.0001)$ in Miasteczko Ślaskie and on day $40(\beta=6.4, p=0.022)$ in Olkusz were negatively associated by $\mathrm{TI}_{\text {tot }}$. This contrasts with the benzo[a]pyrene treatment, which included DCM.

\section{Responses to salt}

Salt stress caused an immediate strong decline in BR in soils from all locations (on average by $41 \%$ for Miasteczko Śląskie and $43 \%$ for Olkusz; Fig. 3a). In the Miasteczko Ślaskie transect, the negative effect of salt stress on BR increased with time (decreased by $52 \%$ at day 60 for Miasteczko Ślaskie; Fig. 3a). Regression analysis indicated that reductions in BR on day $20(\beta=6.4$, $p<0.0001)$, day $40(\beta=8.1, p<0.0001)$, and day $60(\beta=$ $7.8, p<0.0001)$ were strongest at the lowest $\mathrm{TI}_{\text {tot }}$ values (M4-M6). In the Olkusz transect, the negative effect of salt stress on BR also increased over time (64\% decline at day 60; Fig. 3a). This negative effect was again more pronounced in the lesser polluted soils $(\mathrm{O} 4-\mathrm{O} 6)$ while also the extent of change in BR on days $40(\beta=3, p=$ $0.0079)$ and $60(\beta=4.4, p<0.0001)$ were negatively affected by $\mathrm{TI}_{\text {tot }}$.

A rapid change in community composition occurred across the Miasteczko Ślaskie gradient within 1 day of salt stress (on average $45 \%$ similarity on day 1 ; Fig. $3 \mathrm{~b}$ ). However, there was no significant difference between locations. In the Miasteczko Śląskie gradient, similarities between 

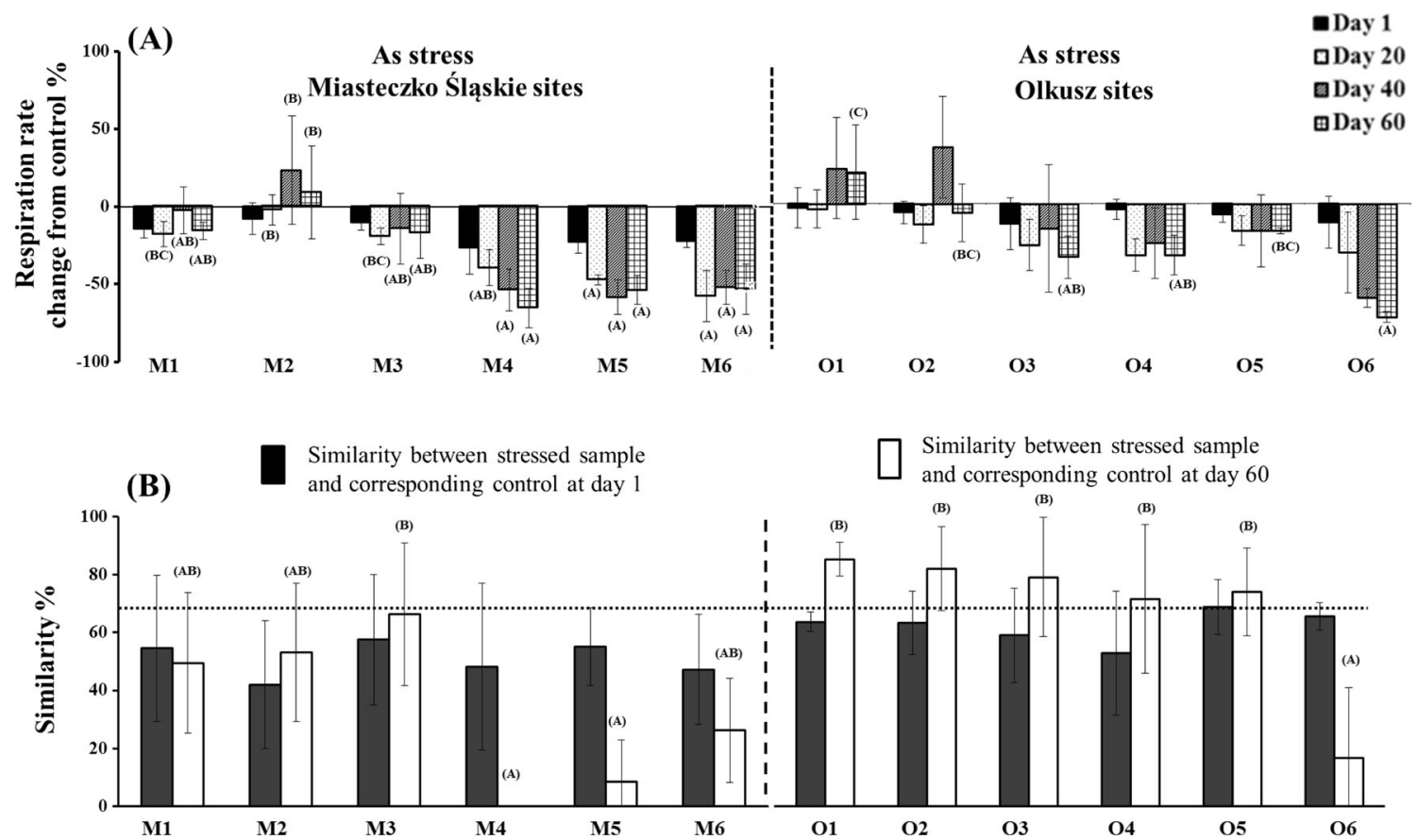

Fig. 1 Arsenic (As(V): $2 \mathrm{~g} \mathrm{~kg}^{-1}$ dry weight) as secondary stressor in metal-polluted forest soils. The samples were derived from 12 locations along two metal pollution gradients in Miasteczko Śląskie (M1-M6; running from high to low metal pollution) and Olkusz (O1-O6; also going from high to low pollution) southern Poland. a Percentage change in basal respiration rate relative to the corresponding control. Negative values indicate inhibition, and positive values indicate stimulation of basal respiration. Different letters indicate that the change in BR was significantly different (Tukey's HSD, $p<0.05$ ) between locations, at a particular time point $(1,20,40$, or 60 days after stress

application) in each gradient separately. b Percentage similarity (Pearson correlation coefficient) between bacterial community fingerprints of additionally stressed soil and the corresponding control. The horizontal dotted lines indicate the average similarity in DGGE profiles for control samples. Different letters indicate that the change in community fingerprints was significantly different (Tukey's HSD, $p<0.05$ ) between locations, at a particular time point ( 1 or 60 days after stress application) for each gradient separately; no letter means no significant difference
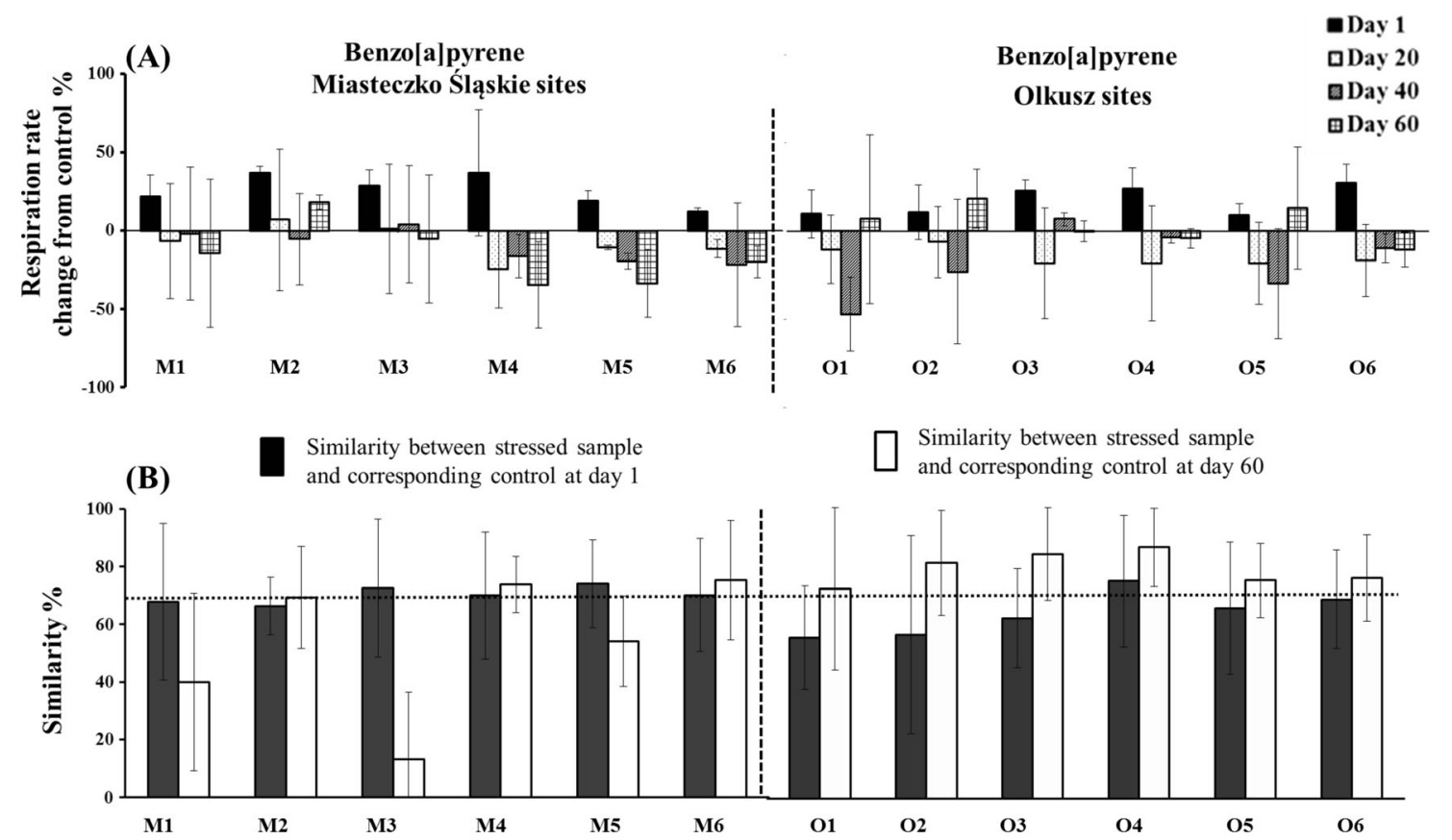

Fig. 2 Benzo[a]pyrene $\left(0.5 \mathrm{~g} \mathrm{~kg}^{-1}\right.$ dry weight $)$ as secondary stressor in metal polluted forest soils along two gradients. a Percentage change in basal respiration rate relative to the corresponding control. b Percentage

similarity (Pearson correlation coefficient) between bacterial community fingerprints of additionally stressed soil and the corresponding control. See description for Fig. 1 for more details 


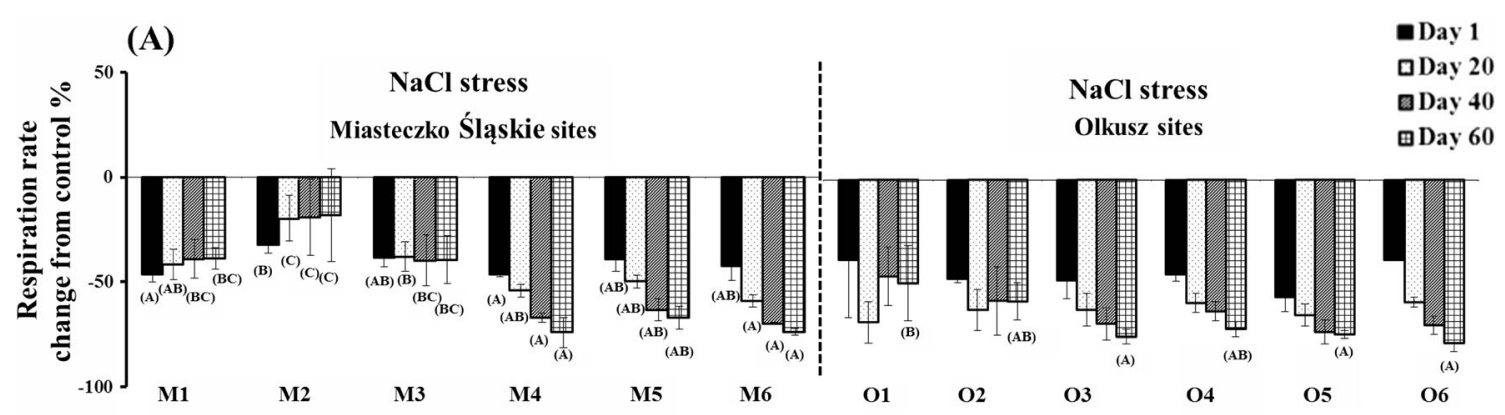

(B)

Similarity between stressed sample and corresponding control at day 1

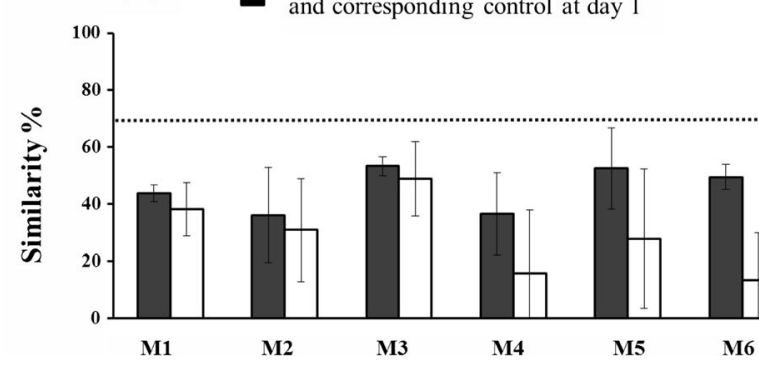

Fig. 3 Salt $\left(6.5 \mathrm{~g} \mathrm{~kg}^{-1}\right.$ dry weight $)$ as secondary stressor in metal polluted forests soils along two gradients. a Percentage change in basal respiration rate relative to the corresponding control. b Percentage

similarity (Pearson correlation coefficient) between bacterial community fingerprints of additionally stressed soil and the corresponding control. See description for Fig. 1 for more details

communities in salt-stressed soils and corresponding controls declined over time and communities in the stressed soils had become more divergent than the controls after 60 days (on average $29 \%$ similar; Fig. 3b). Regression analysis revealed that the similarity of bacterial communities in stressed soils to their corresponding control on day $60(\beta=2.2, p=0.039)$ was positively affected by $\mathrm{TI}_{\text {tot }}$, which is in line with the observations on BR at this time point. We observed a slightly different pattern of changes in community composition upon salt stress for the Olkusz gradient, where after 1 day, no significant changes were evident (on average $64 \%$ similar to control; Fig. 3b). Nevertheless, 60 days after applying the salt stress, similarity of DGGE profiles toward corresponding controls had decreased for the lesser polluted soils (to on average $41 \%$ for O4-O6; Fig. 3b), while hardly any change was observed for the more polluted soils (61\% similarity to corresponding control for O1-O3: Fig. 3b).

Regression analysis supported these patterns, indicating that changes in community composition after 60 days of salt exposure $(\beta=3.7, p=0.002)$ were significantly associated with $\mathrm{TI}_{\text {tot }}$.

A significant positive correlation (Mantel test; $R=0.67$, $p<0.001$ ) between change in microbial community composition and BR response was only observed for the Olkusz transect, at day 60 .

\section{Responses to flooding}

Flooding stress had only minor effects on BR, and no significant differences (less than $10 \%$ change) between locations in each transect were observed throughout the entire incubation period (Fig. 4a). Community composition also showed no change in comparison with corresponding controls, both at day 1 and day 60 (always more than $70 \%$ similar to the corresponding controls; Fig. 4b).

\section{Comparison of microbial communities exposed to different stressors}

On average, the similarities in soil communities corresponding to a particular location along one of the transects and exposed for 60 days to the same stressor were high (withinstress similarities of $53 \%$ for Miasteczko Ślaskie and $71 \%$ for Olkusz: $71 \%$; Fig. 5, white bars; see "Material and methods" for calculation). However, when microbial communities from the same soil sample, after being exposed to different stressors for 60 days, were compared, the resulting between-stress similarities revealed clear differences between the two transects. A clear relation with the level of historical pollution was evident in the Miasteczko Śląskie gradient. Soils with higher $\mathrm{TI}_{\text {tot }}$ showed relatively higher between-stress similarity values (M1-M3: on average 39\% similar) than soils with lower $\mathrm{TI}_{\text {tot }}$ (M4-M6: on average $25 \%$; Fig. 5, black bars). Regression analysis revealed that between-stress similarity values of DGGE profiles from the Miasteczko Ślaskie gradient on day 60 were positively affected by $\mathrm{TI}_{\text {tot }}(p=2.1, p=0.048)$. The between-stress similarities were in generally lower than the within-stress similarities.

In contrast, the community composition in samples from the Olkusz transect and exposed to different stressors 


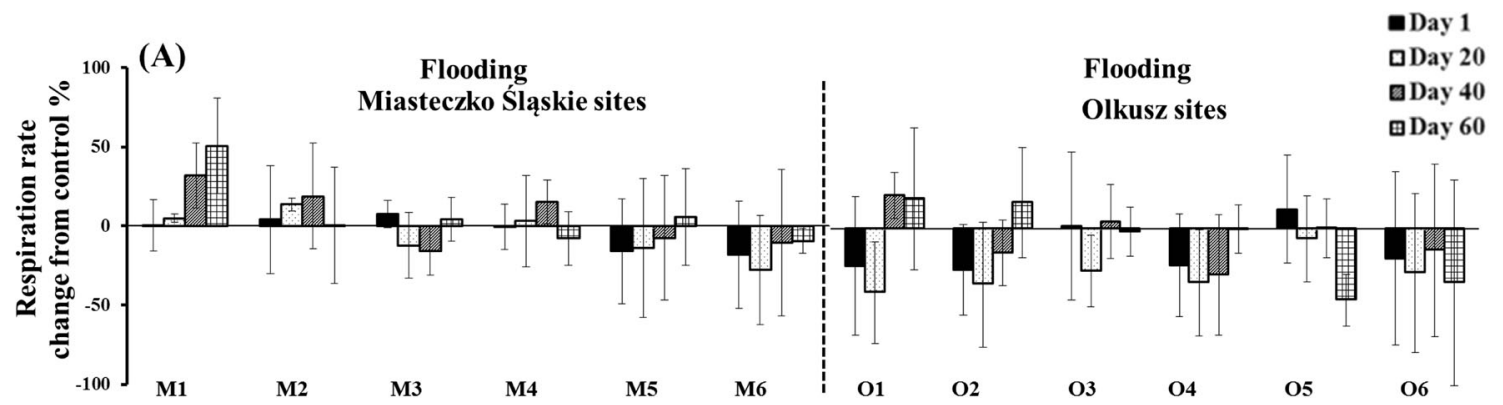

(B) Similarity between stressed sample

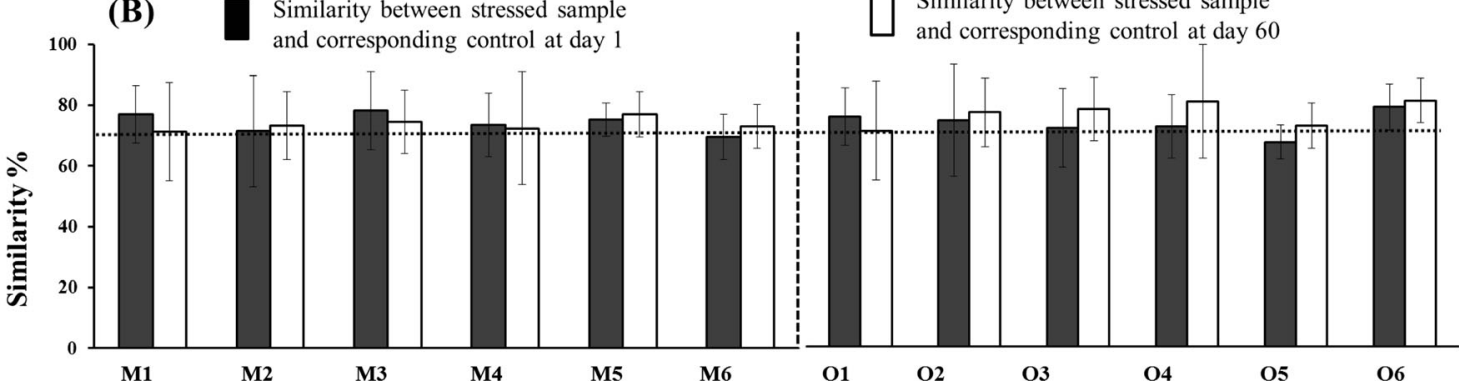

Fig. 4 Flooding (100\% WHC) as secondary stressor in metal polluted forests soils along two gradients. a Percentage change in basal respiration rate relative to the corresponding control. b Percentage similarity

(Pearson correlation coefficient) between bacterial community fingerprints of additionally stressed soil and the corresponding control. See description for Fig. 1 for more details

appeared to be more similar to each other (on average $61 \%$; Fig. 5, black bars). The between-stress similarities were not lower than the within-stress similarities. Soils with higher metal contamination showed higher betweenstress similarities values (O1-O3: on average $71 \%$ ) compared to less polluted soils (O4-O6: on average 52\%; Fig. 5, black bars). Regression analysis corroborated these results, indicating that similarity values at day 60 were positively affected by $\mathrm{TI}_{\text {tot }}(p=3.6, p=0.002)$ along the Olkusz gradient.

\section{Discussion}

\section{Functional and compositional responses to secondary} stressors, in relation to functional potentials

Previous stress-on-stress studies in long-term polluted soils focused on functional aspects such as changes in respiration rates (Tobor-Kapłon et al. 2005, 2006a, b) and enzyme activity (Mertens et al. 2007, 2010) after applying stressors. To improve our understanding of effects or primary and

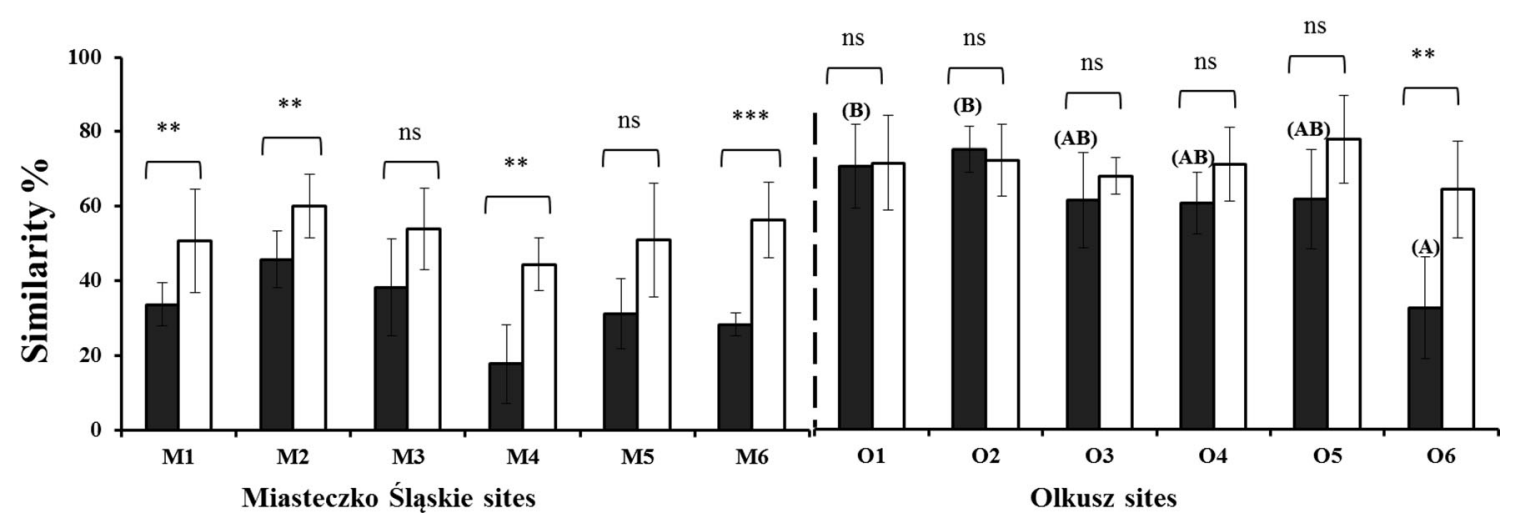

Fig. 5 Similarities in communities exposed to different stressors ("between-stress") were compared to similarities in communities exposed to the same stressor ("within-stress") derived from cluster analysis (Pearson correlation) of DGGE profiles of 16S rRNA gene fragments of bacteria from 12 locations along two pollution gradients in Miasteczko Śląskie (M1-M6) and Olkusz (O1-O6) southern Poland, under different stress. See "Material and methods" for the method of calculation. Error bars indicate standard deviation $(n=3)$. Different letters indicate that the change in community fingerprints was significantly different (Tukey's HSD, $p<0.05$ ) between locations for "between-stress" or "within-stress" similarities in each gradient separately. $n s$ not significant; $* * p<0.01 ; * * * p<0.001$ 
secondary stress, we studied both functional and compositional responses, using $16 \mathrm{~S}$ rRNA gene profiling as an indicator of community composition. We need to point out that BR covers all soil organisms, while the compositional parameter (16S rRNA gene abundance) is focused only on bacteria. Fungi contribute the most to soil basal respiration, especially in organic layers of forest soils (Stefanowicz et al. 2008).

Conflicting results have been reported regarding responses toward secondary stressors (stress-on-stress) in microbial communities exposed to long-term metal-polluted soils (Tobor-Kapłon et al. 2005, 2006a, b). In order to study and interpret the functional and compositional responses toward secondary stress, we took advantage of prior information about the soil microbial communities along the two metalpolluted forest soil gradients (Azarbad et al. 2013, 2015). In the following sections, we discuss how this knowledge on both community composition and functional capabilities, prior to adding the secondary stressor, as well as after adding the stressor, benefitted understanding the functional responses.

Arsenic stress (metalloid stress) Natural background concentrations of arsenic in soil are on average 5 to $10 \mathrm{mg} / \mathrm{kg}$, although this varies among geological regions (Peterson et al. 1981). Arsenic concentrations were only slightly elevated and more or less similar at all study sites in both investigated transects here. In the Miasteczko Slaskie transect, arsenic concentrations varied from $41 \mathrm{mg} \mathrm{kg}^{-1}$ close to the factory to $3.6 \mathrm{mg} \mathrm{kg}^{-1}$ in remote sampling point, and in the Olkusz area, they varied from 56.3 to $6.7 \mathrm{mg} \mathrm{kg}^{-1}$ (Supplementary Table S1). This made arsenic, at $2000 \mathrm{mg} \mathrm{kg}^{-1}$, a relevant secondary stress for our study.

We found that both respiration rate and community composition changed less in the more heavily polluted soils than in the down-gradient soils. This support our hypothesis that soil microbial communities adapted to the higher metal pollution levels (close to the smelters), would be better able to deal with additional metalloid stress than those that experienced a lower pollution level, in accordance with the previously observed changes in the frequency of metal resistance genes (Azarbad et al. 2015). In that study, the pollution level correlated positively with metal resistance genes, including $\operatorname{ars} A$. This gene is a membrane-bound anion translocating ATPase, contributing to detoxification by lowering the intracellular arsenic concentration, thus conferring resistance to $\mathrm{As}(\mathrm{V})$ and As(III) (Saltikov and Olson 2002). The higher frequency of this gene may have been a key factor in the response toward arsenic.

Our results are in line with previous reports on the development of community tolerance induced by heavy metals (Díaz-Raviña et al. 1994; Mertens et al. 2006; Philippot et al. 2008; Deng et al. 2009). Resistance systems often provide cross-resistance to several metals (Nies 2003). Using the thymidine incorporation technique, Díaz-Raviña et al. (1994) showed that soil contaminated with either $\mathrm{Cd}, \mathrm{Ni}, \mathrm{Pb}, \mathrm{Zn}$, or $\mathrm{Cu}$ did not only induce tolerance to the corresponding metal but also to other heavy metals.

Our observations appear to conflict with those reported by Tobor-Kapłon et al. (2005), who did observe an increased sensitivity of a metal-polluted soil when exposed to another metal as secondary stress. In their case, a copper-polluted soil was exposed to lead $\left(1 \mathrm{~g} \mathrm{~kg}^{-1}\right.$ dry weight). Likely reasons for the differences between tolerance are differences in charges ( $\mathrm{As}(\mathrm{V})$ was added as arsenate, an anion, while $\mathrm{Pb}$ (II) is a cation), concentrations of contaminating metals and environmental settings. As microbial community composition was not investigated in parallel by Tobor-Kapłon et al. (2005), it is difficult to pinpoint factors that have contributed to these contrasting observations. A later study on the same Dutch site revealed minor differences in community composition after 27-year exposure to various concentrations of copper (de Boer et al. 2012).

Benzo[a]pyrene stress The initial step of the benzo[a]pyrene degradation pathways commonly occurs via the incorporation of molecular oxygen into the aromatic nucleus by a aromatic ring-hydroxylating-dioxygenases such as naphthalene 1,2dioxygenase (encoded by nahAc and nahAd) (Cébron et al. 2008) and a subsequent oxidation of the dihydrodiol products by a dehydrogenase (e.g., 1,2-dihydroxy-1,2dihydronaphthalene dehydrogenase, encoded by nahB) (Patel and Gibson 1974). The next step in the catabolic pathway is catalyzed by a second dioxygenase which cleaves the ring structure (Harayama et al. 1992). Genes encoding enzymes involved in PAH metabolism were previously detected in all locations along the transects, and their diversity and abundances were not impacted by the level of metal pollution (Azarbad et al. 2015). The presence of putative PAH degrading organisms throughout the transects may explain why the addition of benzo[a]pyrene had a stimulating effect on basal respiration on day 1. Previous studies have shown that many bacterial strains are able to degrade benzo[a]pyrene (Kanaly and Harayama 2000), and unless tightly bound to soil organic matter, benzo[a]pyrene is relatively easily mineralized to carbon dioxide by soil microorganisms (Lu et al. 2011).

Our results are in contrast with our initial prediction that benzo[a]pyrene, as a new stressor in comparison with the initial stress (heavy metal), might have adverse effects especially in the polluted soils. Apparently, long-term selection by heavy metals in the field has not resulted in a decreased capacity to deal with an organic compound, benzo[a]pyrene. The absence of significant changes in BR in Miasteczko Śląskie and Olkusz gradients correlated with an absence in significant shifts in bacterial 
community composition in soils exposed to benzo[a]pyrene stress.

Salt stress Metals incur a metabolic burden to microorganisms as they continuously have to pump out toxic metals and repair damage, so it is metabolically expensive to maintain metal resistance mechanisms (Ruyters et al. 2012). Equally, microbes need to investigate substantial energy in order to deal with salt stress to keep sodium out and maintain osmoprotectants at high intracellular concentrations (Sleator and Hill 2001).

Therefore, we predicted that the susceptibility of the community to salt stress would be highest in soils with the highest metal levels, as osmotolerance is a very expensive mechanism and salt stress is more potent than that of heavy metals (Sardinha et al. 2003). Indeed, the strongest effects were observed upon salt stress. In general, salt stress caused a substantial reduction in BR by 52 and $64 \%$ on day 1 in Miasteczko Śląskie and Olkusz, respectively.

The reduced respiration with an increase in salinity in our study is in line with the findings of others (Pankhurst et al. 2001; Wichern et al. 2006; Mamilov et al. 2004). Osmotic stress results in dehydration and lysis of cells and thus inhibits microbe-mediated decomposition and mineralization processes (Wichern et al. 2006). Nevertheless, in our case, the most polluted sites showed a smaller change in BR and community composition compared to the less polluted sites. The increased tolerance to salt stress in polluted sites can be explained as an effect of the ionic strength in soils polluted by many metals at the same time. High metal exposure therefore might select not only for metal tolerance but also for tolerance to high osmotic pressure, making them more resistant against salt treatment (Díaz-Raviña and Bååth 1996).

Our results on salt stress are again in contrast with the findings of Tobor-Kapłon et al. (2005). While after addition of salt, respiration showed no differences in their copperpolluted and control soils in resistance, the soils without copper contamination showed higher resilience (recovery) during 2 months of exposure. Furthermore, we cannot easily relate our results on salt stress to changed abundances of osmotic stress genes such as opuE, proV, proW, and proX. These were not impacted by the long-term exposure to high metal pollution (Azarbad et al. 2015).

Flooding BR and community composition in both transects were not susceptible to flooding. Since the maximum water holding capacity which was used in this study is also reached naturally during (heavy) rainfall, soils likely already contained the microbial taxa that allowed the communities to remain active during flooding. Our previous GeoChip data on the abundance of functional genes support these results; the data indicated that microbial communities were functionally diverse in oxygen stress and oxygen limitation in all locations, and that these potentials were not affected by the level of pollution (Azarbad et al. 2015).

\section{Functional responses in relation to changes in community composition, biomass, and soil properties}

The phylogenetic and functional richness of the microbial communities were previously observed to be unaffected by the level of historical pollution (Azarbad et al. 2015). Therefore, we conclude that soils with similar diversity can respond differently to additional stressors. This emphasizes the need to focus on microbial community composition rather than biodiversity (i.e., species richness) since the biological characteristics of individual species within a community can have an impact on ecosystem function.

While there were no differences in diversity, there were differences in microbial biomass along the gradients: the least polluted soils contained up to more than ten times higher biomass per gram soil than the most polluted soils (Azarbad et al. 2013). Therefore, we expected that the fastest responses and recoveries would be observed for the less polluted soils, which have the largest pool of stress-resistant microorganisms. However, the smallest changes of respiration upon salt or arsenic stress were actually observed for the most polluted soils. In the least polluted soils, respiration did not recover to presecondary stress levels over the time frame of the experiment (60 days). In fact, the generally negative impact of the stressor on respiration enhanced over time. At the same time also community composition changed, indicating that this change was related to ongoing toxicity rather than indicative of recovery. The continuing decline of respiration over time was likely due to dying microorganisms, leading to lower biomass levels: we had previously established that biomass, and associated respiration, negatively correlated with metal concentrations in the two transects after many years of exposure (Azarbad et al. 2013).

The different response patterns found across all locations under different classes of stressors may relate to an activation of different physiological stress responses. Studying two forest gradients with comparable levels of pollutants allowed us to check whether soil microbial communities along these gradients responded similarly to stressors. Differences in both functional and compositional responses were observed between the two gradients and, in general, effects of stressors on community composition were more pronounced in the Miasteczko Ślaskie than in the Olkusz transect (Fig. 5). One possible explanation for these differences in response could be the higher $\mathrm{pH}$ values in Olkusz transect compared to the Miasteczko Ślaskie transect (Supplementary Table S1). Thus, the response of soil microbial communities to additional stressors may also depend on soil properties. 


\section{Conclusion}

Using two separate gradients, polluted by different smelters, the present study demonstrates that, overall, functional and compositional responses to arsenic and salt stress were clearly related to the level of pollution in the long-term contaminated soils. In addition, these changes could for a large part (except for salt stress) be understood in terms of the abundances of functional genes already present in the microbial communities before the secondary stressor was added. Our findings demonstrate that the historical level of metal pollution can be important when attempting to predict microbial responses to environmental perturbations. In addition, microbial communities selected for metal resistance did not show a loss of their capacity to deal with additional stress, in fact for some stress factors (arsenic and salt) their resistance was increased rather than decreased. This observation may be taken to argue that adaptation should not be considered a negative phenomenon in risk assessment.

Acknowledgments This study was performed within a PRELUDIUM Grant of the Polish National Science Center (No. UMO-2012/05/N/NZ8/ 00925) and "Environmental stress, population viability and adaptation" project (No. MPD/2009-3/5) and supported by the DS759 of the Institute of Environmental Sciences, Jagiellonian University.

Open Access This article is distributed under the terms of the Creative Commons Attribution 4.0 International License (http:// creativecommons.org/licenses/by/4.0/), which permits unrestricted use, distribution, and reproduction in any medium, provided you give appropriate credit to the original author(s) and the source, provide a link to the Creative Commons license, and indicate if changes were made.

\section{References}

Azarbad H, Niklińska M, van Gestel CAM, Van Straalen NM, Röling WFM, Laskowski R (2013) Microbial community structure and functioning along metal pollution gradients. Environ Toxicol Chem 32:1992-2002

Azarbad H, Niklińska M, Laskowski R, van Straalen NM, van Gestel CAM, Zhou J, He Z, Wen C, Röling WFM (2015) Microbial community composition and functions are resilient to metal pollution along two forest soil gradients. FEMS Microbiol Ecol 91:1-11

Bååth E, Frostegård A, Díaz-Raviña M, Tunlid A (1998) Microbial community-based measurements to estimate heavy metal effects in soil: the use of phospholipid fatty acid patterns and bacterial community tolerance. Ambio 27:58-61

Boivin MEY, Greve GD, Kools SAE, Wurff AWG, Leeflang P, Smit E, Breure AM, Rutgers M, Straalen NM (2006) Discriminating between effects of metals and natural variables in terrestrial bacterial communities. Appl Soil Ecol 34:103-113

Brinch UC, Ekelund F, Jacobsen CS (2002) Method for spiking soil samples with organic compounds. Appl Environ Microbiol 68: $1808-1816$

Cébron A, Norini MP, Beguiristain T, Leyval C (2008) Real-Time PCR quantification of PAH-ring hydroxylating dioxygenase (PAH-
RHDa) genes from Gram positive and Gram negative bacteria in soil and sediment samples. J Microbiol Methods 73:148-159

De Boer TE, Taș N, Braster M, Temminghoff EJM, Röling WFM, Roelofs D (2012) The influence of long-term copper contaminated agricultural soil at different $\mathrm{pH}$ levels on microbial communities and springtail transcriptional regulation. Environ Sci Technol 46:60-68

Degens BP, Schipper LA, Sparling GP, Duncan LC (2001) Is the microbial community in a soil with reduced catabolic diversity less resistant to stress or disturbance? Soil Biol Biochem 33:1143-1153

Deng H, Li XF, Cheng WD, Zhu YG (2009) Resistance and resilience of $\mathrm{Cu}$-polluted soil after $\mathrm{Cu}$ perturbation, tested by a wide range of soil microbial parameters. FEMS Microbiol Ecol 70:293-304

Díaz-Raviña M, Bååth E (1996) Development of metal tolerance in soil bacterial communities exposed to experimentally increased metal levels. Appl Environ Microbiol 62:2970-2977

Díaz-Raviña M, Bååth E, Frostegård A (1994) Multiple heavy metal tolerance of soil bacterial communities and its measurement by a thymidine incorporation technique. Appl Environ Microbiol 60: 2238-2247

Domsch KH (1984) Effects of pesticides and heavy metals on biological processes in soil. Plant Soil 76:367-378

Fierer N, Schimel J, Holden P (2003) Variations in microbial community composition through two soil depth profiles. Soil Biol Biochem 35: $167-176$

Frostegård Å, Tunlid A, Bååth E (1996) Changes in microbial community structure during long-term incubation in two soils experimentally contaminated with metals. Soil Biol Biochem 28:55-63

Fry JC (1996) Biological data analysis: a practical approach. Oxford University Press, Oxford, United Kingdom

Grodziński W, Greszta J, Laskowski R, Maryański M, Rozen A (1990) Effect of the chemical composition of industrial dusts on forest floor organic matter accumulation. Water Air Soil Pollut 53:169-178

Harayama S, Kok M, Neidle EL (1992) Functional and evolutionary relationships among diverse oxygenases. Annu Rev Microbiol 46: 565-601

Jones KC, Alcock RE, Johnson DL, Northcott GL, Semple KT, Woolgar PJ (1996) Organic chemicals in contaminated land: analysis, significance and research priorities. Land Contam Reclam 4:189-197

Kanaly RA, Harayama S (2000) Biodegradation of high-molecularweight polycyclic aromatic hydrocarbons by bacteria. J Bacteriol 182:2059-2067

Kools SAE, Berg MP, Boivin MEY, Kuenen FJA, van der Wurff AG, van Gestel CAM, van Straalen NM (2008) Stress responses investigated; application of zinc and heat to Terrestrial Model Ecosystems from heavy metal polluted grassland. Sci Total Environ 406:462-468

Kuan HL, Hallett PD, Griffiths BS, Gregory AS, Watts CW, Whitmore AP (2007) The biological and physical stability and resilience of a selection of Scottish soils to stresses. Eur J Soil Sci 58:811-821

Laskowski R, Maryański M, Niklińska M (1994) Effect of heavy metals and mineral nutrients on forest litter respiration rate. Environ Pollut 84:97-102

Lu Z, Deng Y, Van Nostrand JD, He Z, Voordeckers J, Zhou A, Lee Y-J, Mason OU, Dubinsky EA, Chavarria KL, Tom LM, Fortney JL, Lamendella R, Jansson JK, D'haeseleer P, Hazen TC, Zhou J (2011) Microbial gene functions enriched in the Deepwater Horizon deep-sea oil plume. ISME J 6:451-460

Mamilov A, Dilly OM, Mamilov S, Inubushi K (2004) Microbial ecophysiology of degrading Aral Sea wetlands: consequences for Ccycling. J Soil Sci Plant Nutr 50:839-842

Mertens J, Springael D, De Troyer I, Cheyns K, Wattiau P, Smolders E (2006) Long-term exposure to elevated zinc concentrations induced structural changes and zinc tolerance of the nitrifying community in soil. Environ Microbiol 8:2170-2178

Mertens J, Ruyters S, Springael D, Smolders E (2007) Resistance and resilience of zinc tolerant nitrifying communities is unaffected in long-term zinc contaminated soil. Soil Biol Biochem 39:1828-1831 
Mertens J, Wakelin SA, Broos K, McLaughlin MJ, Smolders E (2010) Extent of copper tolerance and consequences for functional stability of the ammonia-oxidizing community in long-term copper-contaminated soils. Environ Toxicol Chem 29:27-37

Müller AK, Rasmussen LD, Sørensen SJ (2001) Adaptation of the bacterial community to mercury contamination. FEMS Microbiol Lett 204:49-53

Muyzer G, Teske A, Wirsen CO, Jannasch HW (1995) Phylogenetic relationships of Thiomicrospira species and their identification in deep-sea hydrothermal vent samples by denaturing gradient gel electrophoresis of 16S rDNA fragments. Arch Microbiol 164:165-172

Nies DH (2003) Efflux-mediated heavy metal resistance in prokaryotes. FEMS Microbiol Rev 27:313-339

Niklińska M, Chodak M, Laskowski R (2005) Characterization of the forest humus microbial community in a heavy metal polluted area. Soil Biol Biochem 37:2185-2194

Nowicki M (1993) Environment in Poland-issues and solutions. Ministry of Environmental Protection, Natural Resources and Forestry, Kluwer Academic Publishers, Dordrecht

Pankhurst CE, Yu S, Hawke BG, Harch BD (2001) Capacity of fatty acid profiles and substrate utilization patterns to describe differences in soil microbial communities associated with increased salinity or alkalinity at three locations in South Australia. Biol Fertil Soils 33: 204-217

Patel TR, Gibson DT (1974) Purification and properties of (+)cisnaphthalenedihydrodiol dehydrogenase of Pseudomonas putida. J Bacteriol 119:879-888

Pennanen T, Frostegård Å, Fritze H, Bååth E (1996) Phospholipid fatty acid composition and heavy metal tolerance of soil microbial communities along two heavy metal-polluted gradients in coniferous forests. Appl Environ Microbiol 62:420-428

Peterson PJ, Benson LM, Zieve R (1981) Metalloids. In: Lepp NW (ed) Effect of heavy metal pollution on plants. Applied Science Publishers, London, pp 279-342

Philippot L, Cregut M, Cheneby D, Bressan M, Dequiet S, MartinLaurent F, Ranjard L, Lemanceau P (2008) Effect of primary stresses on resilience and resistance of the soil nitrate reducer community to a subsequent stress. FEMS Microbiol Lett 285:51-57

Roberts DR, Scheinost AC, Sparks DL (2002) Zinc speciation in a smelter-contaminated soil profile using bulk and microspectroscopic techniques. Environ Sci Technol 36:1742-1750
Röling WFM, van Breukelen BM, Braster M, Lin B, van Verseveld HW (2001) Relationships between microbial community structure and hydrochemistry in a landfill leachate-polluted aquifer. Appl Environ Microbiol 67:4619-4629

Ruyters S, Mertens J, Springael D, Smolders E (2012) Co-tolerance to zinc and copper of the soil nitrifying community and its relationship with the community structure. Soil Biol Biochem 44:75-80

Saltikov CW, Olson BH (2002) Homology of Escherichia coli R773 $\operatorname{ars} A, \operatorname{ars} B$, and $\operatorname{ars} C$ genes in arsenic-resistant bacteria isolated from raw sewage and arsenic-enriched creek waters. Appl Environ Microbiol 68:280-288

Sardinha M, Muller T, Schmeisky H, Joergensen RG (2003) Microbial performance in soils along a salinity gradient under acidic conditions. Appl Soil Ecol 23:237-244

Sleator RD, Hill C (2001) Bacterial osmoadaptation: the role of osmolytes in bacterial stress and virulence. FEMS Microbiol Rev 26:49-71

Smith E, Naidu R, Alston AM (1998) Arsenic in the soil environment: a review. Adv Agron 64:149-195

Stefanowicz AM, Niklińska M, Laskowski R (2008) Metals affect soil bacterial and fungal functional diversity differently. Environ Toxicol Chem 27:591-598

Tobor-Kapłon MA, Bloem J, Römkens PFAM, de Ruiter PC (2005) Functional stability of microbial communities in contaminated soils. Oikos 111:119-129

Tobor-Kapłon MA, Bloem J, Römkens PFAM, de Ruiter PC (2006a) Functional stability of microbial communities in contaminated soils near a zinc smelter (Budel, The Netherlands). Ecotoxicology 15: $187-197$

Tobor-Kapłon MA, Bloem J, de Ruiter PC (2006b) Functional stability of microbial communities from long-term stressed soils to additional disturbance. Environ Toxicol Chem 25:1993-1999

Turpeinen R, Kairesalo T, Häggblom MM (2004) Microbial community structure and activity in arsenic, chromium and copper contaminated soils. FEMS Microbiol Ecol 47:39-50

Wichern J, Wichern F, Joergensen RG (2006) Impact of salinity on soil microbial communities and the decomposition of maize in acidic soils. Geoderma 137:100-108

Witter E, Gong P, Bååth E, Marstorp H (2000) A study of the structure and metal tolerance of the soil microbial community six years after cessation of sewage sludge applications. Environ Toxicol Chem 19: 1983-1991 